\title{
PENERAPAN SANKSI DENDA TERHADAP KASUS PERSEKONGKOLAN TENDER JALAN NASIONAL
}

\author{
Kajian Putusan Nomor 430 K/PDT.SUS-KPPU/2015
}

\section{IMPOSING OF FINANCIAL PENALTIES AGAINST THE CONSPIRATION CASE OF NATIONAL ROAD TENDER}

\author{
An Analysis of Decision Number 430 K/PDT.SUS-KPPU/2015 \\ Asmah \\ Fakultas Hukum Universitas Sawerigading Makassar \\ Jl. Kandea 1 No. 27 Makassar 90156 \\ Email: asmahunsa@yahoo.co.id
}

\begin{abstract}
Naskah diterima: 21 Oktober 2017; revisi: 2 Mei 2019; disetujui 19 Agustus 2019
http://dx.doi.org/10.29123/jy.v12i2.280
\end{abstract}

\section{ABSTRAK}

Komisi Pengawas Persaingan Usaha (KPPU) dalam Putusan Nomor 09/KPPU-L/2013 menyatakan bahwa terlapor I, terlapor II, terlapor III, terlapor IV, terlapor V, terlapor VI, terlapor VII, terlapor VIII, terlapor IX, dan terlapor $\mathrm{X}$ terbukti secara sah dan meyakinkan melakukan persekongkolan tender. Pengadilan Negeri Makassar menjatuhkan Putusan Nomor 238/PDT. SUS-KPPU/2014/PN.MKS yang amarnya menolak permohonan keberatan para pemohon. Pada tingkat kasasi, Mahkamah Agung dalam Putusan Nomor 430 K/PDT.SUS-KPPU/2015 menguatkan Putusan Nomor 238/PDT.SUS-KPPU/2014/PN.MKS dan Putusan Nomor 09/KPPU-L/2013. Rumusan masalah penelitian ini adalah bagaimana analisis penerapan sanksi hukum dalam kasus persekongkolan tender pada Putusan Nomor 430 K/PDT.SUS-KPPU/2015 tingkat kasasi di Mahkamah Agung. Metode yang digunakan adalah normatif empiris. Kesimpulan penelitian ini adalah pertimbangan hakim pada Putusan Nomor 430 K/PDT. SUS-KPPU/2015, yang pada dasarnya menguatkan Putusan Nomor 238/PDT.SUS-KPPU/2014/PN.MKS
\end{abstract}

dan Putusan Nomor 09/KPPU-L/2013 yang menyatakan bahwa terlapor telah terbukti memenuhi unsur-unsur Pasal 22 Undnag-Undang Nomor 5 Tahun 1999 terkait persekongkolan tender, sehingga merefleksikan nilainilai dan norma-norma yang terkandung dalam proses penegakan hukum di bidang persaingan usaha, dengan memberikan jaminan kesempatan berusaha yang sama bagi setiap pelaku usaha melalui pencegahan terjadinya praktik persekongkolan tender.

Kata kunci: sanksi, persekongkolan, KPPU.

\section{ABSTRACT}

The Business Competition Supervisory Commission (KPPU) in Decision Number 09/KPPU-L/2013 states that reported party I up to reported party $X$ were proven legally and convincingly to conduct tender conspiracy. Makassar District Court imposed Decision Number 238/PDT.SUS-KPPU/2014/PN.MKS that refused the petition of petitioners' objections. At the cassation level, the Supreme Court in Decision Number 430 K/PDT. SUS-KPPU/2015 reinforces Decision Number 238/ 
PDT.SUS-KPPU/2014/PN.MKS and Decision Number 09/KPPU-L/2013. The formulation of this research problem is how the analysis of the application of legal sanctions in the case of tender conspiracy in Decision Number 430 K/PDT.SUS-KPPU/2015 cassation level in the Supreme Court. The method used in this analysis is normative. The conclusion of this research is that consideration of the judge on the Decision of the Supreme Court Number 430 K/PDT.SUS-KPPU/2015 that reinforces Decision Number 238/PDT.SUS-

\section{PENDAHULUAN}

\section{A. Latar Belakang}

Program pembangunan di bidang ekonomi dan kesejahteraan masyarakat umum merupakan hal yang sedang giat dilakukan oleh pemerintah saatini. Penghidupan dan sarana utama masyarakat dilakukan pembangunan infrastruktur, baik jalan utama maupun jalan penghubung untuk akses masyarakat, sehingga pemerataan ekonomi dapat terlaksana secara merata dan dampaknya dirasakan oleh masyarakat secara keseluruhan.

Salah satu provinsi yang turut melakukan pembangunan infrastruktur adalah Provinsi Sulawesi Barat. Sebagai provinsi yang baru dibentuk oleh pemerintah pusat, pengerjaan dan pengembangan jalan nasional merupakan hal yang harus dilakukan demi tercapainya akses ekonomi bagi masyarakat. Hal baik yang mestinya dilakukan menjadi tercederai dengan adanya pelanggaran terhadap Undang-Undang Nomor 5 Tahun 1999 tentang Larangan Praktik Monopoli dan Persaingan Usaha Tidak Sehat (Undang-Undang Nomor 5 Tahun 1999) pada tender pekerjaan pelebaran jalan pada Balai Besar Pelaksanaan Jalan Nasional VI Makassar Direktorat Jenderal Bina Marga, Kementerian Pekerjaan Umum Tahun Anggaran 2012.
KPPU/2014/PN.MKS and KPPU Decision Number 09/KPPU-L/2013, which states that the reported party has been proven to fulfill the elements of Article 22 of Law 5 of 1999 related to the tender conspiracy. So that it reflects, the values and norms that contained in the process of law enforcement in the field of business competition, by providing guarantees of equal business opportunities for each business actor through the prevention of the practice of tender conspiracy.

Keywords: sanctions, conspiracy, KPPU.

Komisi Pengawas Persaingan Usaha (KPPU) sebagai lembaga yang berwenang melakukan penanganan terhadap pelanggaran dalam Undang-Undang Nomor 5 Tahun 1999, telah menerima laporan dari masyarakat tentang adanya persekongkolan tender pada Satuan Kerja Pelaksanaan Jalan Nasional Provinsi Sulawesi Barat Tahun Anggaran 2012.

Persekongkolan tender tersebut dilakukan oleh terlapor I (Pokja Pengadaan Wilayah I), terlapor II (Pokja Pengadaan Wilayah II), terlapor III (PT P), terlapor IV (PT AU), terlapor V (PT USS), terlapor VI (PT SJP), terlapor VII (PT $\mathrm{BBI}$ ), terlapor VIII (PT PJ), terlapor IX (PT LGP), dan terlapor X (PT DIPM) pada Tender Pekerjaan Pelebaran Jalan pada Balai Besar Pelaksanaan Jalan Nasional VI Makassar Direktorat Jenderal Bina Marga, Kementerian Pekerjaan Umum Tahun Anggaran 2012.

\section{Pasal 22 Undang-Undang Nomor 5} Tahun 1999 berbunyi: "Pelaku usaha dilarang bersekongkol dengan pihak lain untuk mengatur dan atau menentukan pemenang tender sehingga dapat mengakibatkan terjadinya persaingan usaha tidak sehat." Dalam perspektif KPPU, persekongkolan tender adalah bagian dari empat jenis praktik hardcore cartel, yaitu 
persekongkolan tender, pembagian wilayah, pengaturan suplai, serta pengaturan harga. Sejak tahun 2000 sampai dengan 2015, telah ada 152 kasus persekongkolan tender yang dilaporkan dan diperiksa serta diputus oleh KPPU. Dari 152 kasus tersebut, 126 di antaranya terdapat instansi pemerintah sebagai pihak terlapor (KPPU, 2017: 216).

Berdasarkan dugaan pelanggaran yang dilakukan para terlapor, KPPU menjatuhkan Putusan Nomor 09/KPPU-L/2013 yang menyatakan bahwa para terlapor terbukti secara sah dan meyakinkan melanggar Pasal 22 Undang-Undang Nomor 5 Tahun 1999, dan menghukum terlapor III membayar denda sebesar Rp10.108.000.000,-; terlapor IV membayar denda sebesar Rp4.234.575.000,-; terlapor V membayar denda sebesar Rp3.680.300.000,-; terlapor VI membayar denda sebesar Rp3.438.900.000,terlapor VII membayar denda sebesar Rp3.296.475.000,-; terlapor VIII membayar denda sebesar Rp2.128.650.000,-; terlapor IX membayar denda sebesar Rp2.932.500.000,dan terlapor $\mathrm{X}$ membayar denda sebesar Rp1.000.000.000,-.

Pihak pelaku usaha yang telah dinyatakan secara sah dan meyakinkan melanggar Pasal 22 Undang-Undang Nomor 5 Tahun 1999 mengajukan banding ke Pengadilan Negeri Makassar. Terhadap keberatan tersebut, Pengadilan Negeri Makassar menjatuhkan Putusan Nomor 238/PDT.SUS-KPPU/2014/ PN.MKS yang amarnya menolak permohonan keberatan para pemohon. Tidak sampai di situ, para pelaku usaha tersebut melanjutkan upaya hukum kasasi, karena Putusan Pengadilan Negeri Makassar kurang cukup mempertimbangkan fakta dan alasan-alasan keberatan para pemohon. Pada tingkat kasasi, permohonan kasasi yang diajukan oleh para pemohon kasasi (para terlapor dalam Putusan Nomor 09/KPPU-L/2013) tersebut ditolak dengan Putusan Nomor $430 \mathrm{~K} /$ PDT.SUS-KPPU/2015.

Berdasarkan Putusan Nomor 430 K/PDT. SUS-KPPU/2015 pada tingkat kasasi, telah menguatkan Putusan Nomor 09/KPPU-L/2013. Namun putusan tersebut tidak membuat para pelaku usaha yang dinyatakan telah bersalah oleh KPPU menyerah. Para pelaku usaha tersebut kembali mengajukan upaya hukum peninjauan kembali. Hasilnya, Mahkamah Agung menyatakan menolak permohonan pemeriksaan peninjauan kembali dari para pemohon yang termuat dalam Putusan Nomor 117 PK/PDT. SUS-KPPU/2016.

Mahkamah Agung pada pertimbangan hukumnya menyatakan bahwa alasan-alasan peninjauan kembali tidak dapat dibenarkan karena tidak ditemukan adanya kekhilafan hakim dalam putusan judex juris, dan bukti baru yang diajukan tidak bersifat menentukan. Selain itu di antara para peserta lelang/para pemohon peninjauan kembali terbukti adanya hubungan kekerabatan, dan dokumen-dokumen mengandung kesamaan dan dipersiapkan oleh orang tidak sah, sehingga terbukti adanya persekongkolan.

Putusan ini semakin membuktikan dan mempertegas komitmen KPPU dalam menegakkan dan menjaga pelaksanaan hukum persaingan usaha yang sehat. Putusan Nomor 09/KPPU-L/2013 telah dikuatkan mulai dari tingkat banding, kasasi, dan peninjauan kembali. Dalam tulisan ini peneliti akan berfokus pada pertimbangan hakim yang menguatkan putusan banding dari pelaku usaha di pengadilan negeri dan putusan KPPU. 


\section{B. Rumusan Masalah}

Berdasarkan latar belakang di atas, maka penulis merumuskan rumusan masalah yakni apakah pertimbangan hakim dalam Putusan Nomor 430 K/PDT.SUS-KPPU/2015 sudah tepat ditinjau dari perspektif persaingan usaha?

\section{Tujuan dan Kegunaan}

Tujuan penelitian untuk mengetahui pertimbangan hakim dalam Putusan Nomor 430 K/PDT.SUS-KPPU/2015 sudah tepat ditinjau dari perspektif persaingan usaha. Adapun kegunaan penelitian ini dapat menjadi bahan referensi bagi lembaga peradilan secara umum, dan KPPU secara khusus dalam pengenaan sanksi terhadap larangan persekongkolan tender yang diatur dalam Undang-Undang Nomor 5 Tahun 1999 tentang Larangan Praktik Monopoli dan Persaingan Usaha Tidak Sehat.

\section{Tinjauan Pustaka}

Kegiatan usaha yang terus-menerus diselenggarakan oleh masing-masing orang, mendorong dan melahirkan suatu persaingan usaha antar pelaku usaha seyogianya terjadi sebagai conditio sine qua non, atau persyaratan mutlak bagi terselenggaranya ekonomi pasar, dan dapat dimungkinkan terjadi persaingan tidak sehat (Puspaningrum, 2013: 21). Permasalahan persaingan usaha di Indonesia pada masa orde baru belum mendapat perhatian yang serius dari pemerintah dalam merumuskan kebijakan anti monopoli. Fakta di masa lampau menunjukkan bahwa rezim orde baru telah melakukan monopoli alokasi serta distribusi sumber daya ekonomi yang dikuasainya. Melalui berbagai langkah kebijakan yang dikeluarkannya, negara menentukan alokasi modal, kredit, konsesi, serta lisensi yang pada akhirnya didistribusikan kepada masyarakat. Kekuasaan negara begitu kuat sehingga sangat rawan terhadap bentuk-bentuk penyelewengan kewenangan (abuse of power policy) (Suharsil \& Mohammad, 2010: 14).

Setiap pelanggaran atas hukum persaingan dapat mengakibatkan hilangnya kesejahteraan dari sebagian konsumen dan atau pelaku usaha. Persaingan usaha yang sehat sangat dibutuhkan, maka dibentuklah hukum yang mengatur persaingan usaha, yaitu seperangkat aturan hukum yang mengatur mengenai segala aspek yang berkaitan dengan persaingan usaha, yang mencakup halhal yang boleh dilakukan dan hal-hal yang dilarang dilakukan oleh pelaku usaha (Prasetyo, Saptono \& Tobing, 2016: 2).

\section{Persekongkolan}

\section{a. Konsep Persekongkolan Tender}

Istilah persekongkolan di semua kegiatan masyarakat hampir selalu berkonotasi negatif. Dalam Kamus Besar Bahasa Indonesia persekongkolan berasal dari kata sekongkol, artinya orang yang serta berkomplot melakukan kejahatan, kecurangan, dan sebagainya. Persekongkolan yakni bersekutu, bersepakat melakukan kejahatan (Suharso \& Ana, 2013: 467). Persekongkolan tender termasuk salah satu perbuatan yang dianggap merugikan negara, karena terdapat unsur manipulasi harga penawaran, dan cenderung menguntungkan pihak yang terlibat dalam persekongkolan (Asmah, 2017: 117).

Persekongkolan tender (atau kolusi tender) terjadi ketika pelaku usaha, yang seharusnya bersaing secara tertutup, bersekongkol untuk menaikkan harga atau menurunkan kualitas barang atau jasa untuk para pembeli yang ingin 
memperoleh produk atau jasa melalui suatu proses pengadaan. Organisasi publik dan swasta sering bergantung kepada suatu proses yang kompetitif untuk memperoleh hasil terbaik dengan dana yang tersedia. Harga rendah dan/ atau produk yang lebih baik diinginkan karena mereka menghasilkan sumber daya yang dihemat atau dikurangi untuk digunakan pada barang dan jasa lainnya.

Proses yang kompetitif dapat menghasilkan harga yang lebih rendah atau kualitas dan inovasi yang lebih baik, hanya ketika para perusahaan tersebut bersaing murni (sebagai contoh, menetapkan persyaratan dan kondisi secara jujur dan berdiri sendiri). Persekongkolan dalam tender dapat menjadi merusak apabila ia memengaruhi pengadaan publik. Persekongkolan tersebut mengambil sumber daya dari para pembeli dan pembayar pajak, mengurangi kepercayaan publik dalam proses yang kompetitif, dan mengurangi manfaat suatu pasar yang kompetitif (Lubis et al., 2009: 209).

\section{b. Pengaturan Persekongkolan Tender}

Pasal 1 huruf h Undang-Undang Nomor 5 Tahun 1999 menyatakan persekongkolan atau konspirasi usaha adalah bentuk kerjasama yang dilakukan oleh pelaku usaha dengan pelaku usaha lain dengan maksud untuk menguasai pasar bersangkutan bagi kepentingan pelaku usaha yang bersekongkol. Lebih lanjut UndangUndang Nomor 5 Tahun 1999 mengatur tentang persekongkolan pada pasal:

Pasal 22

Pelaku usaha dilarang bersekongkol dengan pihak lain untuk mengatur dan atau menentukan pemenang tender sehingga dapat mengakibatkan terjadinya persaingan usaha tidak sehat.
Pasal 23

Pelaku usaha dilarang bersekongkol dengan pihak lain untuk mendapatkan informasi kegiatan usaha pesaingnya yang diklasifikasikan sebagai rahasia perusahaan sehingga dapat mengakibatkan terjadinya persaingan usaha tidak sehat.

Pasal 24

Pelaku usaha dilarang bersekongkol dengan pihak lain untuk menghambat produksi dan atau pemasaran barang dan atau jasa pelaku usaha pesaingnya dengan maksud agar barang dan atau jasa yang ditawarkan atau dipasok di pasar bersangkutan menjadi berkurang baik dari jumlah, kualitas, maupun ketepatan waktu yang dipersyaratkan.

Adanya jaminan kepastian hukum berdasarkan Undang-Undang Nomor 5 Tahun 1999 diharapkan dapat mencegah praktik-praktik monopoli dan persaingan usaha tidak sehat, sehingga tercipta efektivitas dan efisiensi dalam kegiatan usaha yang meningkatkan efisiensi nasional sebagai salah satu upaya meningkatkan kesejahteraan rakyat. Dengan terciptanya persaingan usaha yang sehat akan memberikan daya tarik kepada para penanam modal baik dalam negeri maupun asing untuk menanamkan modalnya, dan dengan adanya penanaman modal yang masuk ke Indonesia tentu dapat membuka peluang kerja baru dan berpotensi mengurangi jumlah pengangguran yang pada kenyataannya terus meningkat (Paendong, 2017: 52).

\section{c. Unsur-Unsur Persekongkolan Tender}

Pemenuhan unsur Pasal 22 UndangUndang Nomor 5 Tahun 1999 terdiri dari:

\section{1) Unsur Pelaku Usaha}

Pengertian pelaku usaha dalam Pasal 1 angka 5 Undang-Undang Nomor 5 Tahun 1999 adalah orang perorangan 
atau badan usaha, baik yang berbentuk badan hukum atau bukan badan hukum yang didirikan dan berkedudukan atau melakukan kegiatan dalam wilayah hukum negara Republik Indonesia, baik sendiri maupun bersama-sama melalui perjanjian, menyelenggarakan berbagai kegiatan usaha dalam bidang ekonomi.

\section{2) Unsur Bersekongkol}

Pengertian bersekongkol dalam Peraturan Komisi Pengawas Persaingan Usaha Nomor 2 Tahun 2010 tentang Pedoman Pasal 22 Undang-Undang Nomor 5 Tahun 1999 tentang Larangan Persekongkolan dalam Tender (Pedoman Pasal 22) adalah kerjasama yang dilakukan oleh pelaku usaha dengan pihak lain atas inisiatif siapapun dan dengan cara apapun dalam upaya memenangkan peserta tender tertentu; menurut Pedoman Pasal 22, unsur bersekongkol tersebut dapat berupa:

a. Kerjasama antara dua pihak atau lebih.

b. Secara terang-terangan maupun diam-diam melakukan tindakan penyesuaian dokumen dengan peserta lainnya.

c. Membandingkan dokumen tender sebelum penyerahan.

d. Menciptakan persaingan semu.

e. Menyetujui dan atau memfasilitasi terjadinya persekongkolan.

f. Tidak menolak melakukan suatu tindakan meskipun mengetahui atau sepatutnya mengetahui bahwa tindakan tersebut dilakukan untuk mengatur dalam rangka memenangkan peserta tender tertentu.

g. Pemberian kesempatan eksklusif oleh penyelenggara tender atau pihak terkait secara langsung maupun tidak langsung kepada pelaku usaha yang mengikuti tender, dengan cara melawan hukum.

\section{3) Unsur Pihak Lain}

Menurut Pedoman Pasal 22, yang dimaksud dengan unsur pihak lain adalah "para pihak (vertikal dan horizontal) yang terlibat dalam proses tender yang melakukan persekongkolan tender baik pelaku usaha sebagai peserta tender dan atau subjek hukum lainnya yang terkait dengan tender tersebut." Adapun yang dimaksud dengan pihak lain dalam perkara ini adalah para pihak secara horizontal yang merupakan pelaku usaha sebagai peserta tender, maupun pihak lain secara horizontal dan pihak lain secara vertikal yaitu penyelenggara tender yang merupakan subjek hukum lainnya yang terkait dengan tender.

4) Unsur Mengatur dan atau Menentukan Pemenang Tender

Menurut Pedoman Pasal 22, mengatur dan atau menentukan pemenang tender adalah "suatu perbuatan para pihak yang terlibat dalam proses tender secara bersekongkol yang bertujuan untuk menyingkirkan pelaku usaha lain sebagai pesaingnya dan/ atau untuk memenangkan peserta tender tertentu dengan berbagai cara. Pengaturan dan atau penentuan pemenang tender 
tersebut antara lain dilakukan dalam hal penetapan kriteria pemenang, persyarataan teknik, keuangan, spesifikasi, proses tender, dan sebagainya."

5) Unsur Dapat Mengakibatkan Terjadinya Persaingan Usaha Tidak Sehat

Menurut Pasal 1 angka 6 dan Pedoman Pasal 22, persaingan usaha tidak sehat adalah "persaingan antar pelaku usaha dalam menjalankan kegiatan produksi dan atau pemasaran barang dan atau jasa yang dilakukan dengan cara tidak jujur atau melawan hukum atau menghambat persaingan usaha."

\section{d. Jenis Persekongkolan Tender}

Persekongkolan tender menurut Pedoman Pasal 22 tentang Larangan Persekongkolan Tender (KPPU, 2017: 10-12), dapat dibedakan menjadi tiga jenis, yaitu: persekongkolan horizontal, persekongkolan vertikal, dan gabungan antara persekongkolan vertikal dan horizontal. Penjelasan mengenai jenis dari persekongkolan tender tersebut yaitu:

Persekongkolan horizontal, merupakan persekongkolan yang terjadi antara pelaku usaha atas penyedia barang dan jasa dengan sesama pelaku usaha atau penyedia barang dan jasa pesaingnya. Persekongkolan ini dapat dikategorikan sebagai persekongkolan dengan menciptakan persaingan semu di antara peserta tender.

Persekongkolan vertikal, merupakan persekongkolan yang terjadi antara salah satu atau beberapa pelaku usaha atau penyedia barang dan jasa dengan panitia tender atau panitia lelang atau pengguna barang dan jasa atau pemilik atau pemberi pekerjaan. Persekongkolan ini dapat terjadi dalam bentuk panitia tender atau panitia lelang atau pengguna barang dan jasa atau pemilik atau pemberi pekerjaan bekerja sama dengan salah satu atau beberapa peserta tender.

Gabungan persekongkolan horizontal dan vertikal, merupakan persekongkolan antara panitia tender atau panitia lelang atau pengguna barang dan jasa atau pemilik atau pemberi pekerjaan dengan pelaku usaha atau penyedia barang dan jasa. Persekongkolan ini dapat melibatkan dua atau tiga pihak yang terkait dalam proses tender.

\section{e. Sanksi Kegiatan Persekongkolan Tender}

Persekongkolan atau konspirasi usaha adalah bentuk kerjasama yang dilakukan oleh pelaku usaha dengan pelaku usaha lain dengan maksud untuk menguasai pasar bersangkutan bagi kepentingan pelaku usaha yang bersekongkol (Pasal 1 huruf $\mathrm{h}$ UndangUndang Nomor 5 Tahun 1999). Pada pemberian sanksi sebagaimana hakikatnya suatu aturan yang hadir di tengah masyarakat diharapkan lebih komprehensif, terutama berkaitan dengan pengaturan persaingan usaha yang tertuang dalam Undang-Undang Nomor 5 tahun 1999. Bukan berarti aturan-aturan terdahulu tidak baik, namun secara pragmatis batasan-batasan yuridis terhadap praktik bisnis yang tidak sehat sifatnya lebih sektoral sehingga konsep untuk memenuhi berbagai sasaran perlindungan hukum persaingan usaha (Meyliana, 2013: 35).

Sanksi yang diatur dalam UndangUndang Nomor 5 Tahun 1999 terdiri dari tindakan administratif, pidana pokok, dan pidana tambahan, yaitu: 
Tindakan Administratif

Pasal 47

(1) Komisi berwenang menjatuhkan sanksi berupa tindakan administratif terhadap pelaku usaha yang melanggar ketentuan undang-undang ini.

(2) Tindakan administratif sebagaimana dimaksud dalam ayat (1) dapat berupa:

a. penetapan pembatalan perjanjian sebagaimana dimaksud dalam Pasal 4 sampai dengan Pasal 13, Pasal 15, dan Pasal 16; dan atau

b. perintah kepada pelaku usaha untuk menghentikan integrasi vertikal sebagaimana dimaksud dalam Pasal 14; dan atau

c. perintah kepada pelaku usaha untuk menghentikan kegiatan yang terbukti menimbulkan praktik monopoli dan atau menyebabkan persaingan usaha tidak sehat dan atau merugikan masyarakat; dan atau

d. perintah kepada pelaku usaha untuk menghentikan penyalahgunaan posisi dominan; dan atau

e. penetapan pembatalan atas penggabungan atau peleburan badan usaha dan pengambilalihan saham sebagaimana dimaksud dalam Pasal 28; dan atau

f. penetapan pembayaran ganti rugi; dan atau

g. pengenaan denda serendahrendahnya Rp1.000.000.000,- (satu miliar rupiah) dan setinggi-tingginya Rp25.000.000.000,- (dua puluh lima miliar rupiah).

Pidana Pokok

Pasal 48

(1) Pelanggaran terhadap ketentuan Pasal 4, Pasal 9 sampai dengan Pasal 14, Pasal 16 sampai dengan Pasal 19, Pasal 25, Pasal 27, dan Pasal 28 diancam pidana denda serendah-rendahnya Rp25.000.000.000,(dua puluh lima miliar rupiah) dan setinggi tingginya Rp100.000.000.000,- (seratus miliar rupiah), atau pidana kurungan pengganti denda selama-lamanya 6 (enam) bulan.

(2) Pelanggaran terhadap ketentuan Pasal 5 sampai dengan Pasal 8, Pasal 15, Pasal 20 sampai dengan Pasal 24, dan Pasal 26 undang-undang ini diancam pidana denda serendah-rendahnya Rp5.000.000.000,(lima miliar rupiah) dan setinggi-tingginya Rp25.000.000.000,- (dua puluh lima miliar rupiah), atau pidana kurungan pengganti denda selama-lamanya 5 (lima) bulan.

(3) Pelanggaran terhadap ketentuan Pasal 41 undang-undang ini diancam pidana denda serendah-rendahnya Rp1.000.000.000,(satu miliar rupiah) dan setinggi-tingginya Rp5.000.000.000,- (lima miliar rupiah), atau pidana kurungan pengganti denda selama-lamanya 3 (tiga) bulan.

Pidana Tambahan

Pasal 49

Dengan menunjuk ketentuan Pasal 10 Kitab Undang-undang Hukum Pidana, terhadap pidana sebagaimana diatur dalam Pasal 48 dapat dijatuhkan pidana tambahan berupa:

a. pencabutan izin usaha; atau

b. larangan kepada pelaku usaha yang telah terbukti melakukan pelanggaran terhadap undang-undang ini untuk menduduki jabatan direksi atau komisaris sekurangkurangnya 2 (dua) tahun dan selamalamanya 5 (lima) tahun; atau

c. penghentian kegiatan atau tindakan tertentu yang menyebabkan timbulnya kerugian pada pihak lain.

\section{Komisi Pengawas Persaingan Usaha}

Komisi Pengawas Persaingan Usaha (KPPU) adalah lembaga yang tepat untuk menyelesaikan persoalan persaingan usaha yang mempunyai peran multifunctional dan keahlian sehingga dianggap mampu menyelesaikan dan mempercepat proses penanganan perkara (Rokan, 2010: 264). KPPU sebagai lembaga penegak hukum persaingan, memiliki kewenangan untuk menjatuhkan sanksi tindakan administratif dalam rangka mencegah dan/atau mengembalikan kesejahteraan yang hilang tersebut (Usman, 2013: 208). KPPU memiliki beberapa kewenangan di antaranya yaitu:

a. Menerima laporan dari masyarakat dan atau dari pelaku usaha tentang dugaan terjadinya praktik monopoli 
dan atau persaingan usaha tidak sehat.

b. Melakukan penelitian tentang dugaan adanya kegiatan usaha dan atau tindakan pelaku usaha yang dapat mengakibatkan terjadinya praktik monopoli dan atau persaingan usaha tidak sehat.

c. Melakukan penyelidikan dan atau pemeriksaan terhadap kasus dugaan praktik monopoli dan atau persaingan usaha tidak sehat yang dilaporkan oleh masyarakatatauolehpelakuusahaatau menghadirkan pelaku usaha, saksi, saksi ahli, atau setiap orang sebagaimana dimaksud huruf $e$ dan huruf $f$, yang tidak bersedia memenuhi panggilan Komisi.

d. Meminta keterangan dari instansi pemerintah dalam kaitannya dengan penyelidikan dan atau pemeriksaan terhadap pelaku usaha yang melanggar ketentuan undang-undang ini.

e. Mendapatkan, meneliti, dan atau menilai surat dokumen, atau alat bukti lain guna penyelidikan dan atau pemeriksaan.

f. Memutuskandanmenetapkanadaatau tidak adanya kerugian di pihak pelaku usaha lain atau masyarakat.

g. Memberitahukan putusan Komisi kepada pelaku usaha yang diduga melakukan praktik monopoli dan atau persaingan usaha tidak sehat. Menjatuhkan sanksi berupa tindakan administratif kepada pelaku usaha yang melanggar ketentuan UndangUndang Nomor 5 Tahun 1999 (Muhammad, 2016: 58).

\section{METODE}

Tipe penelitian yang penulis gunakan adalah penelitian hukum normatif, yang dilakukan untuk mencari atau menemukan masalah isu hukum dan permasalahan hukum yang ada. Hasil dari penelitian ini adalah memberikan preskripsi mengenai isu hukum yang diajukan. Pendekatan yang digunakan dalam penelitian hukum ini adalah pendekatan perundang-undangan (statute approach), diperlukan guna mengkaji lebih lanjut mengenai landasan hukum dengan menelaah undang-undang dan regulasi yang bersangkut paut dengan isu hukum yang sedang ditangani (Marzuki, 2014: 133), serta pendekatan konseptual (conceptual approach) yaitu beranjak dari pandangan-pandangan dan doktrin-doktrin yang berkembang di dalam ilmu hukum. Peneliti akan menemukan ide-ide yang melahirkan pengertian-pengertian hukum, konsep-konsep hukum dan asas-asas hukum yang relevan dengan isu yang dihadapi (Marzuki, 2014: 135).

\section{HASIL DAN PEMBAHASAN}

Penjelasan Pasal 22 Undang-Undang Nomor 5 Tahun 1999 menyebutkan bahwa tender adalah tawaran mengajukan harga untuk memborong suatu pekerjaan, untuk mengadakan barang-barang atau untuk menyediakan jasa. Dalam hal ini tidak disebut jumlah yang mengajukan penawaran oleh beberapa atau oleh pelaku usaha dalam hal penunjukan langsung. Pengertian tender tersebut mencakup tawaran mengajukan harga untuk memborong atau melaksanakan suatu pekerjaan, mengadakan barang dan jasa, membeli suatu barang dan atau jasa, menjual suatu barang dan atau jasa.

Pasal 22 Undang-Undang Nomor 5 Tahun 1999 disebutkan unsur persekongkolan tender meliputi pelaku usaha, persekongkolan, unsur pihak lain, mengatur dan menentukan pemenang tender, dan persaingan usaha tidak sehat. Praktik 
persekongkolan dalam tender merupakan hal yang dilarang karena dapat menimbulkan pesaingan tidak sehat dan bertentangan dengan tujuan dilaksanakannya tender. Adapun tujuan dilaksanakannya tender adalah untuk memberikan kesempatan yang sama kepada pelaku usaha agar dapat ikut menawarkan harga dan kualitas yang bersaing, sehingga pada akhirnya dalam pelaksanaan proses tender tersebut akan didapatkan harga yang termurah dengan kualitas terbaik (Cahyaningtyas, Sudarwanto \& Sulistiyono, 2018: 279).

Pelanggaran terhadap Pasal 22 UndangUndang Nomor 5 Tahun 1999 terjadi karena adanya laporan dari masyarakat. KPPU melakukan kewajiban dan tanggung jawab sebagaimana amanat Pasal 35 Undang-Undang Nomor 5 Tahun 1999, bahwa KPPU berhak melakukan penilaian atas perjanjian atau kegiatan yang dilarang. KPPU melakukan penelitian, penyelidikan, menyimpulkan hasil penyelidikan, kemudian melakukan pemanggilan dan menghadirkan saksi-saksi, yaitu saksi ahli dan meminta keterangan dari instansi pemerintah dalam kaitannya dengan penyelidikan dan memeriksa dokumen, sehingga menghasilkan kesimpulan bahwa PT P bersama perusahaan lain telah melakukan pelanggaran terhadap Pasal 22 Undang-Undang Nomor 5 Tahun 1999.

Pertimbangan hukum yang dimuat dalam Putusan Nomor 09/KPPU-L/2013 bahwa para pemohon terlapor I sampai dengan $\mathrm{X}$ dalam memenangkan tender proyek lelang pelebaran jalan di Provinsi Sulawesi Barat telah melanggar Pasal 22 Undang-Undang Nomor 5 Tahun 1999 dengan melakukan bentuk persekongkolan vertikal, dalam hal pihak termohon I dan pihak termohon II memfasilitasi para termohon III, IV, V, VI dalam memenangkan proses tender tersebut. Dalam pemeriksaan perkaraperkara persekongkolan tender, KPPU harus membuktikan unsur-unsur yang terkandung dalam Pasal 22 Undang-Undang Nomor 5 Tahun 1999.

Unsur tersebut meliputi pelaku usaha, bersekongkol, pihak lain mengatur dan/atau menentukan pemenang tender dan persaingan usaha tidak sehat. Unsur 'pihak lain' dapat meliputi panitia tender maupun pelaku usaha yang tidak terlibat secara langsung dalam penawaran tender. Unsur bersekongkol dalam UndangUndang Nomor 5 Tahun 1999 mengandung pengertian yang luas. Pemenuhan Unsur Pasal 22 Undang-Undang Nomor 5 Tahun 1999 pada Putusan Nomor 09/KPPU-L/2013 terdiri dari:

\section{1) Unsur Pelaku Usaha}

Pengertian pelakuusaha dalam Pasal 1 angka 5 Undang-Undang Nomor 5 Tahun 1999 adalah orang perorangan atau badan usaha, baik yang berbentuk badan hukum atau bukan badan hukum yang didirikan dan berkedudukan atau melakukan kegiatan dalam wilayah hukum negara Republik Indonesia, baik sendiri maupun bersama-sama melalui perjanjian, menyelenggarakan berbagai kegiatan usaha dalam bidang ekonomi. Pelaku usaha dalam perkara ini adalah terlapor III, terlapor IV, terlapor V, terlapor VI, terlapor VII, terlapor VIII, terlapor IX, dan terlapor X. Dengan demikian unsur pelaku usaha terpenuhi.

\section{2) Unsur Bersekongkol}

Pengertian bersekongkol dalam Peraturan Komisi Pengawas Persaingan Usaha Nomor 2 Tahun 2010 tentang Pedoman Pasal 22 UndangUndang Nomor 5 Tahun 1999 tentang Larangan Persekongkolan dalam Tender (Pedoman Pasal 22) adalah kerjasama yang dilakukan oleh pelaku 
usaha dengan pihak lain atas inisiatif siapapun dan dengan cara apapun dalam upaya memenangkan peserta tender tertentu; menurut Pedoman Pasal 22, unsur bersekongkol tersebut dapat berupa:

a. Kerjasama antara dua pihak atau lebih.

b. Secara terang-terangan maupun diam-diam melakukan tindakan penyesuaian dokumen dengan peserta lainnya.

c. Membandingkan dokumen tender sebelum penyerahan.

d. Menciptakan persaingan semu.

e. Menyetujui dan atau memfasilitasi terjadinya persekongkolan.

f. Tidak menolak melakukan suatu tindakan meskipun mengetahui atau sepatutnya mengetahui bahwa tindakan tersebut dilakukan untuk mengatur dalam rangka memenangkan peserta tender tertentu.

g. Pemberian kesempatan eksklusif oleh penyelenggara tender atau pihak terkait secara langsung maupun tidak langsung kepada pelaku usaha yang mengikuti tender, dengan cara melawan hukum.

Adanya komunikasi dan kerjasama baik secara terang-terangan maupun diam-diam yang dilakukan terlapor III, terlapor IV, terlapor V, dan terlapor VI dibuktikan dengan adanya keterkaitan hubungan keluarga dan hubungan kerja antara pemegang saham dan komisaris, kesamaan pemegang saham antara perusahaan dan kepemilikan saham pada terlapor III, terlapor IV, terlapor V, dan terlapor VI dalam mengikuti tender.

Penyusunan dokumen penawaran para terlapor dilakukan oleh pihak yang sama yang dibuktikan dengan adanya kesamaan format metode pelaksanaan dan informasi softcopy dokumen penawaran. Pengaturan dan penentuan pemenang tender yang dilakukan para terlapor dengan cara menggunakan pihak lain sebagai perusahaan pendamping untuk memenangkan perusahaan tertentu melalui aritmatika penawaran dan penggunaan personil terlapor X.

Tindakan terlapor I dan terlapor II yang tidak transparan terkait jadwal pelaksanaan tender yang tidak lengkap dimaksudkan untuk memfasilitasi terlapor III, terlapor IV, terlapor V, dan terlapor VI sebagai pemenang pada tender. Tindakan terlapor I dan terlapor II dengan menggunakan metode koreksi aritmatika adalah merupakan bentuk memfasilitasi terlapor III, terlapor IV, terlapor V, dan terlapor VI sebagai pemenang pada tender a quo. Tindakan terlapor II yang menginformasikan adanya surat dugaan persekongkolan kepada terlapor III merupakan bentuk komunikasi dan kerjasama antara terlapor II dan terlapor III untuk memenangkan terlapor III sebagai pemenang.

Persekongkolan yang dilakukan oleh para terlapor memenuhi unsur persekongkolan karena terbukti terjadi unsur persekongkolan dengan cara menciptakan persaingan semu di antara peserta tender, melakukan tindakan sebagai perusahaan pendamping, penyusunan dokumen penawaran oleh pihak yang sama berupa adanya kesamaan format metode pelaksanaan, dan adanya kesamaan informasi softcopy dokumen penawaran, adanya keterkaitan hubungan 
keluarga antara pemegang saham dan komisaris, kesamaan pemegang saham antara perusahaan dan kepemilikan saham pada perusahaan yang sama mempermudah koordinasi dan kerjasama dalam menentukan pemenang tender. Serta dengan adanya tindakan memfasilitasi yang dilakukan oleh panitia dengan cara tidak adanya transparansi terkait jadwal pelaksanaan tender, melakukan komunikasi dengan peserta tender, dan menggunakan metode koreksi aritmatika untuk menentukan pemenang tender. Dengan demikian unsur bersekongkol terpenuhi.

\section{3) Unsur Pihak Lain}

Menurut Pedoman Pasal 22, yang dimaksud dengan unsur pihak lain adalah "para pihak (vertikal dan horizontal) yang terlibat dalam proses tender yang melakukan persekongkolan tender baik pelaku usaha sebagai peserta tender dan atau subjek hukum lainnya yang terkait dengan tender tersebut." Adapun yang dimaksud dengan pihak lain dalam perkara ini adalah para pihak secara horizontal yang merupakan pelaku usaha sebagai peserta tender, maupun pihak lain secara horizontal dan pihak lain secara vertikal yaitu penyelenggara tender yang merupakan subjek hukum lainnya yang terkait dengan tender.

Pihak lain secara horizontal adalah perusahaan yang mengikuti tender tetapi tidak memenangkan paket pekerjaan, dan perusahaan yang tidak mengikuti tender tetapi terlibat dalam kerjasama dalam mengatur pemenang pada Paket Kalukku-Salubatu II, Paket Baras-Karossa, Paket Kalukku-Salubatu I, Paket Topoyo-Barakang, dan Paket Lingkar Bandara Tampa Padang, yaitu terlapor VII, terlapor VIII, terlapor IX, dan terlapor X. Yang menjadi pihak lain secara vertikal di Paket Lingkar Bandara Tampa Padang adalah terlapor I (Pokja Pengadaan Wilayah I), dan di Paket Kalukku-Salubatu II, Paket BarasKarossa, Paket Kalukku-Salubatu I, dan Paket Topoyo- Barakang adalah terlapor II. Dengan demikian unsur pihak lain terpenuhi.

\section{4) Unsur Mengatur dan atau Menentukan Pemenang Tender}

Menurut Pedoman Pasal 22, mengatur dan atau menentukan pemenang tender adalah "suatu perbuatan para pihak yang terlibat dalam proses tender secara bersekongkol yang bertujuan untuk menyingkirkan pelaku usaha lain sebagai pesaingnya dan/atau untuk memenangkan peserta tender tertentu dengan berbagai cara. Pengaturan dan atau penentuan pemenang tender tersebut antara lain dilakukan dalam hal penetapan kriteria pemenang, persyaratan teknik, keuangan, spesifikasi, proses tender, dan sebagainya."

Penentuan pemenang tender dilakukan dengan cara terlapor I dan terlapor II memfasilitasi kerjasama antar perusahaan dalam mengikuti proses tender, tidak transparan dalam melakukan proses tender, memfasilitasi hasil koreksi aritmatika yang signifikan, dan melakukan upaya pengaturan pemenang tender pada proses evaluasi. Serta terlapor III, terlapor IV, terlapor V, terlapor VI, terlapor VII, terlapor VIII, terlapor IX, dan terlapor X dalam menciptakan persaingan semu di antara peserta tender dengan cara melakukan tindakan sebagai perusahaan pendamping, penyusunan dokumen penawaran oleh pihak yang sama berupa adanya kesamaan format metode pelaksanaan dan adanya kesamaan informasi softcopy dokumen penawaran, adanya keterkaitan hubungan keluarga antara pemegang saham dan komisaris. Kesamaan pemegang saham antara perusahaan dan kepemilikan saham pada perusahaan yang sama mempermudah koordinasi dan kerjasama 
dalam menentukan pemenang tender. Dengan demikian unsur mengatur dan atau menentukan pemenang tender terpenuhi.

5) Unsur Dapat Mengakibatkan Terjadinya Persaingan Usaha Tidak Sehat

Menurut Pasal 1 angka 6 dan Pedoman Pasal 22, persaingan usaha tidak sehat adalah "persaingan antar pelaku usaha dalam menjalankan kegiatan produksi dan atau pemasaran barang dan atau jasa yang dilakukan dengan cara tidak jujur atau melawan hukum atau menghambat persaingan usaha."

Tindakan-tindakan terlapor III, terlapor IV, terlapor V, terlapor VI, terlapor VII, terlapor VIII, dan terlapor IX dalam menciptakan persaingan semu di antara peserta tender, melakukan tindakan sebagai perusahaan pendamping, penyusunan dokumen penawaran oleh pihak yang sama berupa adanya kesamaan format metode pelaksanaan dan adanya kesamaan informasi softcopy dokumen penawaran, adanya keterkaitan hubungan keluarga antara pemegang saham dan komisaris. Kesamaan pemegang saham antara perusahaan dan kepemilikan saham pada perusahaan yang sama mempermudah koordinasi dan kerjasama dalam menentukan pemenang tender merupakan tindakan yang menghambat persaingan usaha.

Tindakan terlapor I dan terlapor II yang memfasilitasi terjadinya persekongkolan horizontal oleh terlapor III, terlapor IV, terlapor $\mathrm{V}$, terlapor VI, terlapor VII, terlapor VIII, dan terlapor X merupakan tindakan yang menghambat persaingan usaha. Dengan demikian unsur dapat mengakibatkan terjadinya persaingan usaha tidak sehat terpenuhi.

Pengenaan sanksi denda bagi para terlapor dalam kasus persekongkolan tender oleh
Majelis Komisi merujuk pada Peraturan Komisi Pengawas Persaingan Usaha Nomor 4 Tahun 2009 tentang Pedoman Tindakan Administratif sesuai Ketentuan Pasal 47 Undang-Undang Nomor 5 Tahun 1999 tentang Larangan Persekongkolan dalam Tender (Pedoman Pasal 47).

Sanksi denda bertujuan untuk mengambil keuntungan yang didapatkan oleh pelaku usaha yang dihasilkan dari tindakan anti persaingan. Selain itu denda juga ditujukan untuk menjerakan pelaku usaha agar tidak melakukan tindakan serupa atau ditiru oleh calon pelanggar lainnya. Majelis Komisi menentukan besaran denda dengan menempuh dua langkah, yaitu: penentuan besaran nilai dasar, dan penyesuaian besaran nilai dasar dengan menambahkan dan/atau mengurangi besaran nilai dasar tersebut.

Berdasarkan Pedoman Pasal 47, proporsi harga penawaran tender yang diperhitungkan menjadi besaran nilai dasar adalah sampai dengan $10 \%$ (sepuluh persen) dari harga penawaran pemenang tender. Majelis Komisi mempertimbangkan berbagai macam faktor, yaitu: skala perusahaan, aset dan omset perusahaan, jenis pelanggaran, cakupan wilayah geografis pelanggaran, dan telah atau belum dilaksanakannya pelanggaran tersebut, serta ROK (Risk, Overhead, dan Keuntungan) (disesuaikan) yang diperoleh pemenang tender yang menjadi terlapor dalam perkara a quo.

Jenis pelanggaran persekongkolan tender adalah pelanggaran yang paling berat dalam perkara persaingan usaha, sehingga Majelis Komisi menentukan nilai dasar denda sebesar $10 \%$ (sepuluh persen) dari harga penawaran masing-masing pemenang tender dan dikalikan $100 \%$ (seratus persen) bagi pemenang tender, $30 \%$ bagi perserta tender dalam perkara a quo. 
Adapun hal-hal yang memberatkan dengan perhitungan nilai dasar akan ditambah sampai dengan $100 \%$ (seratus persen).

Terlapor III, terlapor IV, terlapor V, dan terlapor VI yang merupakan penggagas pelanggaran, Majelis Komisi mengenakan tambahan denda masing-masing sebesar 100\% (seratus persen). Terlapor VII, terlapor VIII, dan terlapor IX yang merupakan perusahaan pendamping, Majelis Komisi mengenakan tambahan denda masing-masing sebesar $10 \%$ (sepuluh persen). Terlapor VI, terlapor VII, terlapor VIII, terlapor IX, dan terlapor X yang tidak bersikap kooperatif, Majelis Komisi menambahkan denda masing-masing sebesar 5\% (lima persen), dan mengurangi denda masingmasing sebesar 5\% (lima persen) untuk terlapor III, terlapor IV, dan terlapor V, karena bersikap baik dan kooperatif selama proses pemeriksaan.

KPPU hanya dapat menerapkan sanksi administratif terhadap pihak-pihak yang terkait dengan persekongkolan tender. Apabila 'pihak lain' adalah panitia tender dari unsur pemerintah terbukti mendukung persekongkolan, KPPU tidak dapat menjatuhkan sanksi administratif, melainkan hanya dapat memberikan rekomendasi kepada atasan pejabat yang bersangkutan untuk menjatuhkan sanksi administratif.

Putusan KPPU yang memberi sanksi administratif disebut dengann condemnatoir atau putusan yang bersifat menghukum. Sedangkan putusan yang isinya menyatakan bahwa pelaku usaha tertentu secara sah dan meyakinkan melanggar Pasal 22 Undang-Undang Nomor 5 Tahun 1999 disebut putusan declaratoir atau bersifat menerangkan. Dalam hal putusan KPPU berupa denda dan atau ganti rugi, maka para pihak yang dijatuhi putusan tersebut wajib membayar ke kas negara. Apabila dalam jangka waktu 30 hari setelah putusan berkekuatan tetap, namun pelaku usaha tidak melaksanakannya, maka KPPU melakukan permohonan penetapan eksekusi ke pengadilan negeri. Jika kemudian para pelaku usaha tidak melaksanakannya, maka KPPU akan menyerahkan putusan penetapan eksekusi tersebut kepada polri (penyidik) guna melakukan penyidikan atas ketidakpatuhan para pelaku usaha tersebut.

Saat ini sanksi denda kerap menjadi polemik di kalangan pelaku usaha yang diputus bersalah oleh KPPU. Pelaku usaha kerap mengatakan bahwa pengenaan denda dinilai berpotensi mengganggu iklim usaha dan investasi, sehingga berdampak kontraproduktif terhadap perekonomian nasional. Undang-Undang Nomor 5 Tahun 1999 mengatur ketentuan denda pada Pasal 47 yang menyatakan: "tindakan administrasi sebagaimana dimaksud ayat (1) dapat berupa: (g) Pengenaan denda serendah-rendahnya Rp1.000.000.000,- (satu milyar rupiah) dan setinggi-tingginya Rp25.000.000.000,- (dua puluh lima milyar rupiah)."

Dalam laporan tahunan 2016, KPPU menyebutkan bahwa denda sendiri merupakan salah satu bentuk usaha untuk mengambil keuntungan yang timbul akibat tindakan anti persaingan usaha. Selain itu denda juga ditujukan untuk memberikan efek jera kepada pelaku usaha agar tidak melakukan kembali tindakan serupa atau ditiru oleh calon pelaku usaha lainnya. Maka dari itu, agar efek jera tadi efektif, secara ekonomi denda yang ditetapkan harus bisa menjadi sinyal atau setidaknya dipersepsikan oleh pelanggar sebagai biaya (expected cost) yang jauh lebih besar dibandingkan dengan manfaat (expected benefit) yang didapat dari tindakannya melanggar UndangUndang Persaingan (Hukum Online, 2017). 
Jadi ketika KPPU memutuskan terlapor atau sekelompok terlapor untuk membayar denda, maka KPPU telah melakukan penghitungan secara cermat dengan memperhatikan berbagai aspek. Selama 2016, KPPU telah memutus 22 dari 24 perkara yang sedang berjalan. Dari 22 perkara yang diputus tersebut, KPPU berhasil mengenakan denda senilai Rp350.318.471.156,-. Sebagai contoh, dari tiga perkara yang ditangani KPPU, yakni Putusan Nomor 01/KPPU/KPPU-L/2016, Putusan Nomor 02/KPPU-L/2016, dan Putusan Nomor 03/KPPU-L/2016, total denda yang dikenakan kepada terlapor berjumlah Rp146.533.523.338,-Tentu saja nilai denda yang akan masuk ke kas negara juga akan bertambah (Hukum Online, 2017).

Tuntutan para pemohon dalam mengajukan keberatan kepada Pengadilan Negeri Makassar agar memberikan putusan untuk menyatakan terlapor I dan terlapor II tidak melanggar Pasal 22 Undang-Undang Nomor 5 Tahun 1999 dan menyatakan Putusan KPPU Nomor 09/KPPU-L/2013 telah cacat formal. Pengadilan Negeri Makassar selaku peradilan tingkat banding terhadap putusan KPPU, kurang cukup mempertimbangkan fakta dan alasan-alasan keberatan para pemohon keberatan. Majelis hakim hanya menyandarkan pertimbangannya pada surat penjelasan KPPU tanggal 20 Juni 2014 Nomor 09/KPPU-L/2013 yang diserahkan oleh kuasa hukum termohon kasasi, tanpa memeriksa, meneliti, dan tanpa mempertimbangkan berkas perkara lain.

Pengadilan negeri dalam memutus menerapkan asas prinsip keadilan dalam sebuah perkara yang datang kepadanya, dengan berdasarkan bahwa apa yang telah diputuskan oleh KPPU merupakan putusan yang tepat berdasarkan kewenangan yang melekat kepadanya, melalui Pasal 34 Undang-Undang Nomor 5 Tahun 1999. Sehingga putusan dari pengadilan negeri yang menguatkan KPPU berdasarkan prinsip keadilan dalam masyarakat terutama dalam berusaha, sehingga tujuan dari Undang-Undang Nomor 5 Tahun 1999 untuk kesejahteraan dapat tercapai.

Padatingkatkasasi,menurutpemohon dalam Putusan Nomor 430 K/PDT.SUS-KPPU/2015, Putusan KPPU Nomor 09/KPPU-L/2013 sangat merugikan para pemohon karena tanpa didasarkan alasan hukum yang kuat, sebab pada dasarnya memang tidak pernah ada persaingan usaha tidak sehat atau persekongkolan dalam seluruh proses tender lelang pada paket pekerjaan jalan pada Satuan Kerja Pelaksanaan Jalan Nasional Wilayah I Provinsi Sulawesi Barat Tahun Anggaran 2012. Lebih lanjut dikatakan bahwa terjadinya persekongkolan baik horizontal maupun vertikal hanya didasarkan atas asumsi dan pendapat subjektif majelis komisioner KPPU yang memeriksa perkara a quo.

Putusan tersebut tidak berdasarkan atas keyakinan yang timbul dari fakta-fakta persidangan (beyond a reasonable doubt). Bahwa ternyata fakta-fakta yang terungkap selama persidangan sama sekali berbeda dengan apa yang terdapat dalam Putusan KPPU Nomor 09/KPPU-L/2013, sehingga putusan tersebut tidak mempertimbangkan secara utuh dan lengkap fakta-fakta persidangan, serta tidak mempunyai alasan hukum yang cukup (onvoldoende gemotiveerd).

Mahkamah Agung dalam pertimbangan hukumnya pada Putusan Nomor 430 K/PDT. SUS-KPPU/2015 menyatakan bahwa Putusan Pengadilan Negeri Makassar telah tepat dan benar, serta tidak salah menerapkan hukum. Dengan 
terbuktinya unsur Pasal 22 Undang-Undang Nomor 5 Tahun 1999, maka sangkaan atau laporan yang ditujukan kepada pemohon keberatan harus dinyatakan terbukti, sehingga putusan judex facti dalam hal ini Pengadilan Negeri Makassar telah tepat dan benar. Selanjutnya Mahkamah Agung menyatakan bahwa telah benar adanya kesamaan pemilik dan atau hubungan keluarga dalam kepengurusan antara satu peserta dengan peserta tender lainnya, dan adanya kesamaan dokumen antara dokumen tender peserta yang satu dengan dokumen tender peserta lainnya, serta adanya kesamaan pihak yang menyiapkan dokumen tender tersebut telah cukup membuktikan adanya persekongkolan tender.

Selanjutnya Mahkamah Agung berpendapat bahwa selain itu, keberatan-keberatan pemohon tersebut mengenai penilaian hasil pembuktian yang bersifat penghargaan tentang suatu kenyataan, hal mana tidak dapat dipertimbangkan dalam pemeriksaan pada tingkat kasasi. Karena pemeriksaan dalam tingkat kasasi hanya berkenaan dengan adanya kesalahan penerapan hukum, adanya pelanggaran hukum yang berlaku, adanya kelalaian dalam memenuhi syarat-syarat yang diwajibkan oleh peraturan perundangundangan yang mengancam kelalaian itu dengan batalnya putusan yang bersangkutan, atau bila pengadilan tidak berwenang, atau melampaui batas wewenangnya, sebagaimana yang dimaksud dalam Pasal 30 Undang-Undang Nomor 14 Tahun 1985 jo. Undang-Undang Nomor 5 Tahun 2004 dan perubahan kedua Undang-Undang Nomor 3 Tahun 2009.

Undang-Undang Nomor 5 Tahun 1999 melarang perbuatan pelaku usaha yang bertujuan menghambat atau bertentangan dengan prinsip persaingan usaha yang sehat, antara lain seperti pembatasan akses pasar, kolusi, dan tindakan lain yang bertujuan untuk menghilangkan persaingan. Tidakan lain yang dapat berakibat kepada terjadinya persaingan usaha tidak sehat adalah tindakan persekongkolan untuk mengatur dan atau menentukan pemenang tender sebagaimana diatur oleh Pasal 22 Undang-Undang Nomor 5 Tahun 1999.

Pengaturan pemenang tender tersebut banyak ditemukan pada pelaksanaan pengadaan barang atau jasa yang dilaksanakan oleh pemerintah pusat atau pemerintah daerah, BUMN, dan perusahaan swasta. Untuk itu Pasal 22 Undang-Undang Nomor 5 Tahun 1999 tidak hanya mencakup kegiatan pengadaan yang dilakukan oleh pemerintah, tetapi juga kegiatan pengadaan yang dilakukan oleh perusahaan negara, BUMN, BUMD, dan perusahaan swasta.

Putusan yang diberikan oleh hakim mulai dari keberatan di Pengadilan Negeri Makassar sampai kepada tingkat kasasi dan peninjauan kembali di Mahkamah Agung sudah sesuai dengan fakta hukum dan keadilan dalam masyarakat yang menyetujui Putusan KPPU Nomor 09/KPPU-L/2013. Putusan yang diterbitkan oleh Mahkamah Agung sudah mewakili masyarakat, bahwa telah terbukti secara sah pelaku usaha sebagai peserta tender melakukan persekongkolan tender. Dengan demikian dapat memberikan yurisprudensi bagi hakim yang akan datang ketika terjadi kasus persekongkolan tender berikutnya, mengingat tender proyek hampir ada di setiap daerah di Indonesia. Hal ini dapat menjadi preseden baik bagi penegakan hukum persaingan usaha dan bisa menjadi warning bagi pemerintah daerah, dalam hal ini pemerintah provinsi dan kabupaten, dalam membuat putusan dan pelelangan terhadap setiap pembangunan proyek sehingga tidak terjadi potensi kerugian negara. 


\section{KESIMPULAN}

Pertimbangan hakim pada Putusan Nomor 430 K/PDT.SUS-KPPU/2015 yang pada dasarnya menguatkan Putusan Nomor 238/PDT. SUS-KPPU/2014/PN.MKS dan Putusan KPPU Nomor 09/KPPU-L/2013, yang menyatakan bahwa terlapor telah terbukti memenuhi unsurunsur Pasal 22 Undang-Undang Nomor 5 Tahun 1999 terkait persekongkolan tender, yaitu unsur pelaku usaha, unsur bersekongkol, unsur pihak lain, unsur mengatur dan/atau menentukan pemenang tender, dan unsur dapat mengakibatkan terjadinya persaingan usaha tidak sehat yang dilakukan pada tender proyek pelebaran jalan pada Balai Besar Pelaksanaan Jalan Nasional VI Makassar Direktorat Jenderal Bina Marga, Kementerian Pekerjaan Umum Tahun Anggaran 2012. Putusan tersebut telah merefleksikan nilainilai dan norma-norma yang terkandung dalam proses penegakan hukum di bidang persaingan usaha dengan memberikan jaminan kesempatan berusaha yang sama bagi setiap pelaku usaha melalui pencegahan terjadinya praktik persekongkolan tender.

\section{DAFTAR ACUAN}

Asmah. (2017). Hukum persaingan usaha "hakikat fungsi KPPU.” Makassar: CV SIGn.

Cahyaningtyas, K., Sudarwanto, A.S., \& Sulistiyono, A. (2018, Januari). Kajian hukum persekongkolan tender terhadap pengadaan barang/jasa pemerintah secara elektronik (Studi Kasus Putusan Nomor 03/KPPU/L/2015 dalam tender pekerjaan pelebaran Jalan Merek-Bts. Kab. Simalungun-Bts. Kab. Tanah Karo-Seribu Dolok pada kelompok kerja (Pokja) pengadaan barang/jasa satuan kerja pelaksanaan Jalan Nasional Wilayah I Provinsi Sumatera Utara tahun anggaran 2013). Jurnal Hukum dan Pembangunan Ekonomi, 6(1), 237254.

Hukum Online. (2017, Agustus 11). Menakar besaran denda yang efektif bagi pelaku anti persaingan usaha. Diakses dari https://www.hukumonline. com/berita/baca/lt598d71938cd61/menakar besaran-denda-yang-efektif-bagi-pelaku-antipersaingan-usaha.

Komisi Pengawas Persaingan Usaha [KPPU]. (2017). Hukum persaingan usaha. Jakarta: Komisi Pengawas Persaingan Usaha.

Lubis, A.F. et al. (2009). Hukum persaingan usaha antara teks \& konteks. Jakarta: Komisi Pengawas Persaingan Usaha.

Marzuki, P.M. (2014). Penelitian hukum. Edisi Revisi Cetakan ke-9. Jakarta: Kencana Pranada Media Group.

Meyliana, D. (2013). Hukum persaingan usaha. Malang: Setara Pers.

Muhammad, S.I. (2016). Hukum persaingan usaha di Indonesia (Sebagai upaya penguatan lembaga pengawas persaingan usaha KPPU). Malang: Setara Pers.

Paendong, J.E. (2017, Juni). Perlindungan hukum bagi pelaku usaha kecil dalam persaingan usaha di Indonesia menurut Undang-Undang Nomor 5 Tahun 1999 tentang Larangan Praktik Monopoli dan Persaingan Usaha Tidak Sehat. Jurnal Lex Privatum, 5(4), 52-58.

Prasetyo, A.B., Saptono, H., \& Tobing, N.J.R. (2016). Tinjauan yuridis terhadap pelaksanaan eksekusi atas putusan KPPU khususnya dalam hal tender. Diponegoro Law Review, 5(2), 1-10.

Puspaningrum, G. (2013). Hukum persaingan usaha. Yogyakarta: Aswaja Pressindo. 
Rokan, M.K. (2010). Hukum persaingan usaha (Teori \& praktiknya di Indonesia). Jakarta: Raja Grafindo Persada.

Suharsil \& Mohammad, T. (2010). Hukum larangan praktik monopoli \& persaingan usaha tidak sehat di Indonesia. Bogor: Ghalia Indonesia.

Suharso \& Ana, R. (2013). Kamus Besar Bahasa Indonesia. Edisi Lux, Cetakan kesebelas. Semarang: Widya Karya.

Usman, R. (2013). Hukum persaingan usaha di Indonesia. Jakarta: Sinar Grafika. 